Density:

Dielectric:

Epithermal-neutron: Used for qualitative correlation with moisture profiles; very useful for locating moisture zones.

Interpretation of Logs

Caliper logs from boreholes USW UZ-1 and USW UZ-6 are shown in Figures $1 A$ and $1 B$, respectively. Both of these boreholes had abrupt variations in che borehole sizes.

Water-saturation Calculations and Comparisons

An attempt was made to calculate porosities from density logs. Matrix-density values were obtained from drill cuttings. Porosities were calculated by the following formula:

$$
\phi=\frac{d m-d b}{d m-d f}
$$

where

$$
\begin{aligned}
\phi & =\text { porosity } \\
d m & =\text { matrix density, } 8 \mathrm{r} / \mathrm{cm}^{3}, \\
d b & =\text { bulk density, } 8 \mathrm{r} / \mathrm{cm}^{3}, \text { and } \\
d f & =\text { fluid density, } g r / \mathrm{cm}^{3} .
\end{aligned}
$$

As shown in Figure 2 for borehole USW UZ-1, and in Figure 3 for borehole USW UZ-6, density logs, calculated porosities, and degree of welding, which were determined from cores, samples, etc., correlated very well. As expected, porosities calculated from density logs were greater than porosities determined from core analysis. This difference was caused by the effect of partial gas saturation on bulk-density measurements. Before saturation calculations were made, it was necessary to know the formation-water resistivity. Resistivity logs of a nearby borehole drilled by conventional methods, USW $H=1$, were used 


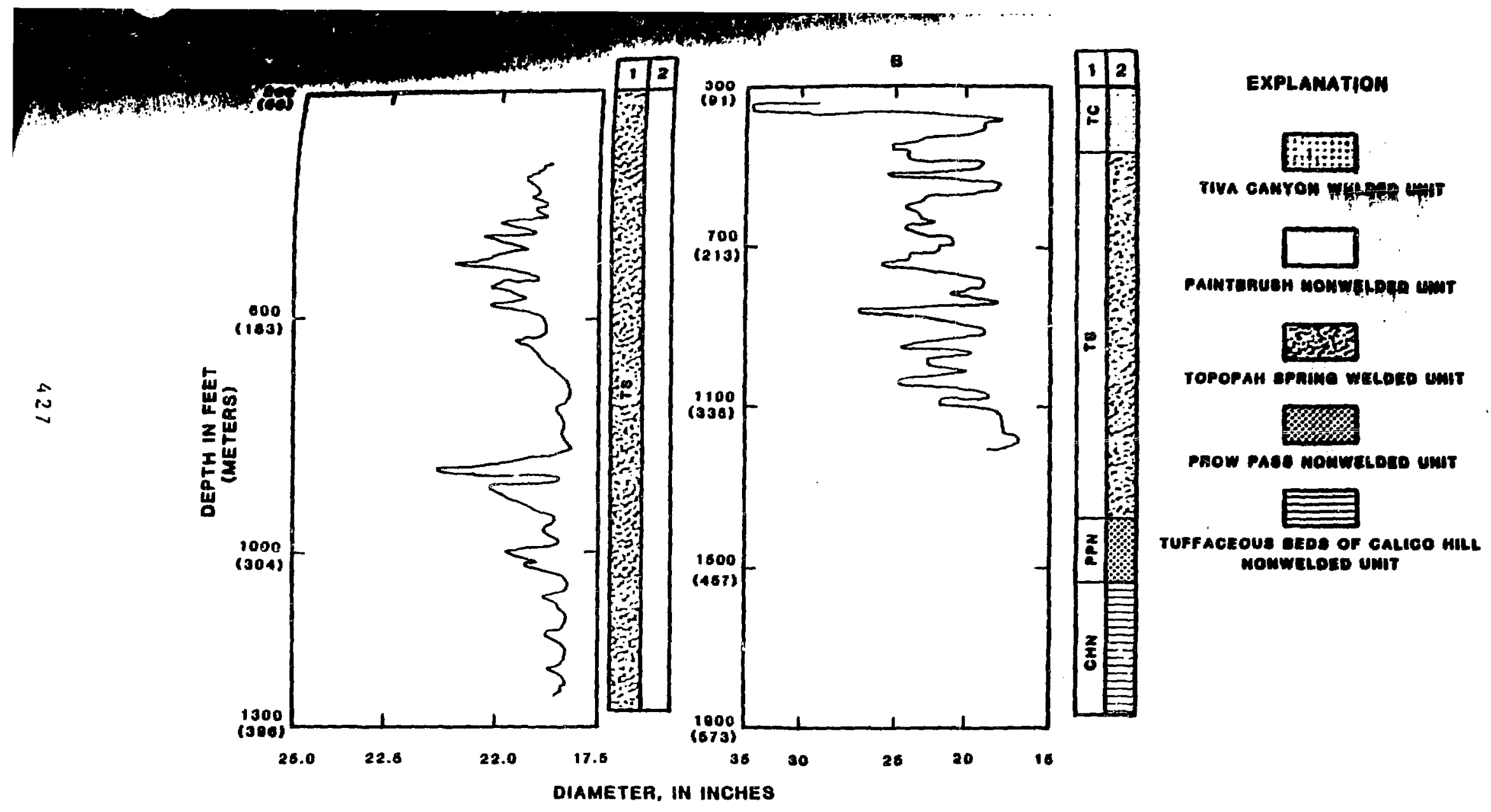

Figure 1. Caliper logs--(A) borehole USW UZ-1, and (B) borehole USW UZ-6--showing the borehole-diameter variation. Drill-bit size for both boreholes is 17.5 inches (44.45 cent imeters). 


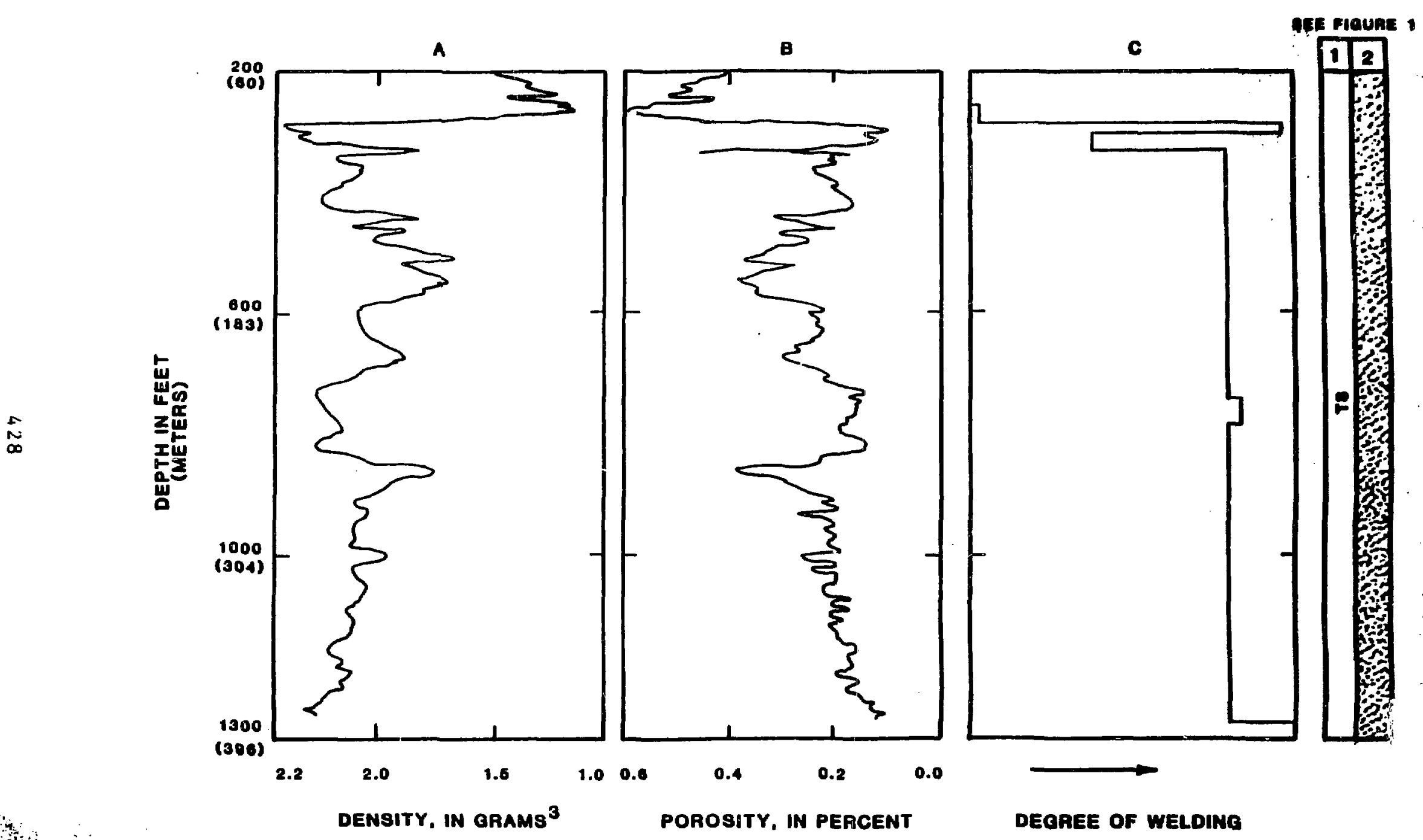

in

DEQREE OF WELDING

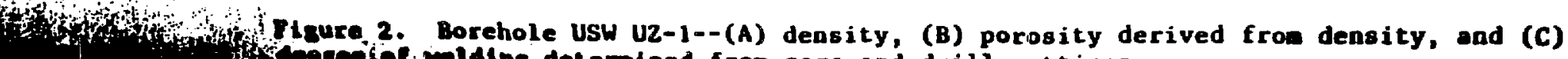

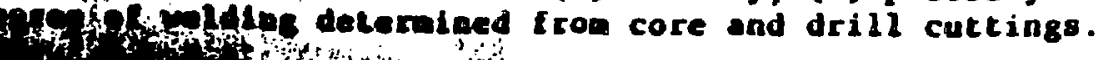




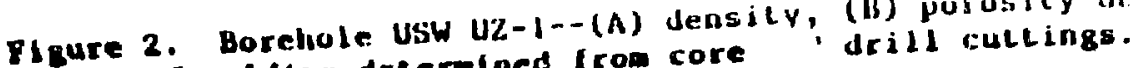

defres of weldtan deterulned from core

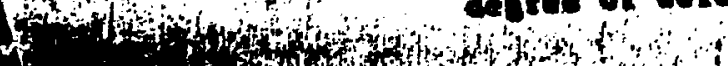

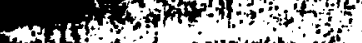
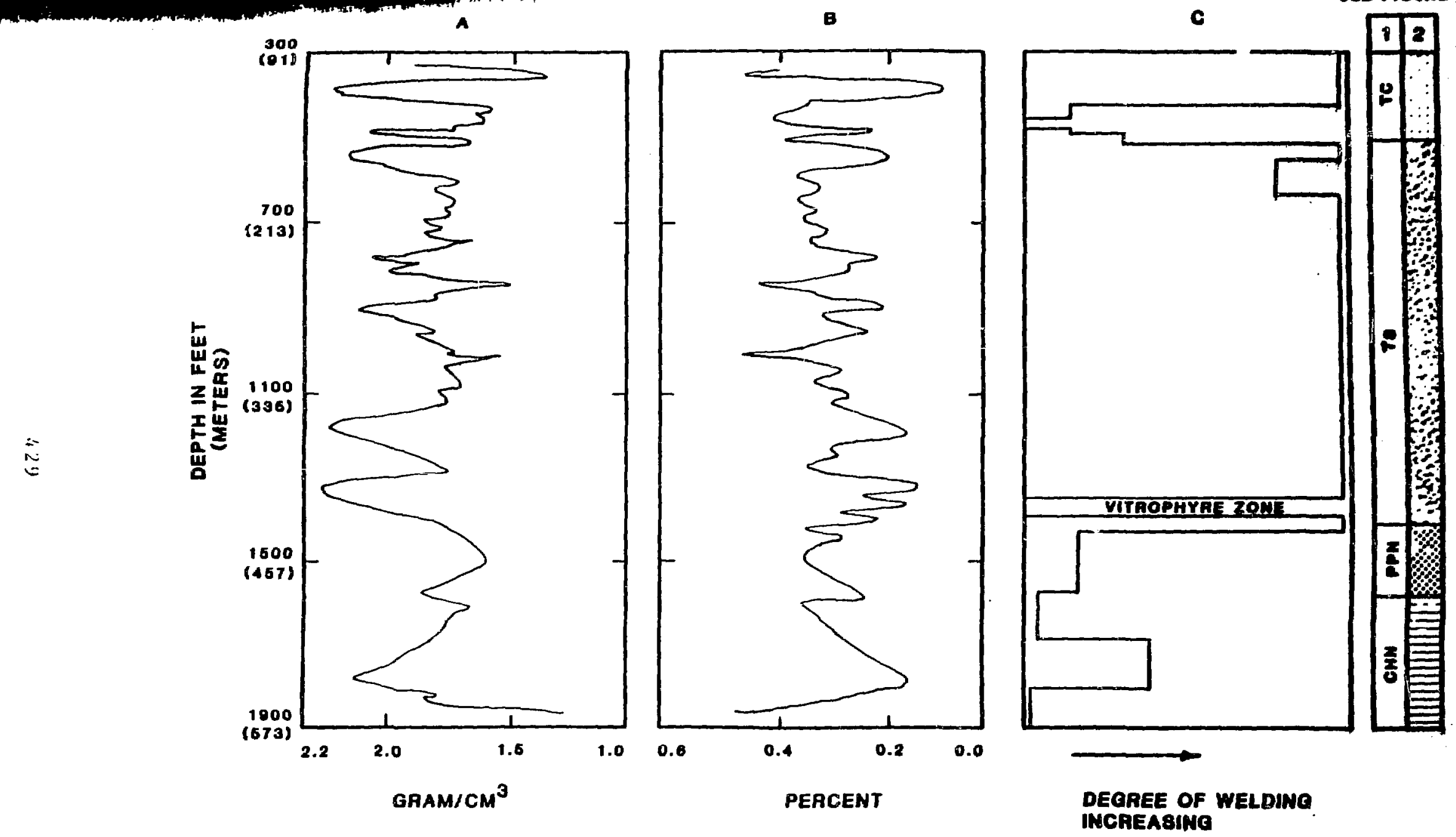

Figure 3, Borehole USW UZ-6--(A) density, (B) porosity derived from density, and (C) degree of welding determined from core and drill cuttings. 
for calculating fornation-water resistivity. Water-saturation values then were calculated by using the following equstion:

$$
s_{w}^{n}=\left(R_{w} / R_{t}\right) 1 / \phi^{n} ; n=n=2.0
$$

where

$$
\begin{aligned}
S_{w} & =\text { water saturation, } \\
\phi & =\text { porosity, } \\
R_{w} & =\text { resistivity of fluid in the rock, ohm- }-\mathrm{m}^{2} / \mathrm{m}, \\
\mathbf{R}_{t} & =\text { true resistivity of the rock, ohm }-\mathrm{m}^{2} / \mathrm{m}, \\
m & =\text { cementation constant, and } \\
\mathbf{n} & =\text { saturation exponent. }
\end{aligned}
$$

It was determined, after testing varying $m$ and $n$ values for different intervals, that water-saturation values did not vary much. Then $m$ and $n$ values were set as 2.0 along the borehole. Water-saturation values also were calculated after taking porosities from the density $\log$ and using the moisture-content profile derived from the dielectric log:

Water saturation $=$ moisture content/porosity.

This saturation profile was compared with the curve determined previously, and the correlation was considered satisfactory. The correlation between water-saturation values derived from formation resistivity and porosity (A) and dielectric constant and porosity (B) is shown in Figure 4 for borehole USW UZ-1, and in Figure 5 for borehole USW UZ-6.

\section{Moisture-content Calculations and Comparisons}

Moisture content was calculated by using dielectric-constant values from the dielectric logs. The empirical equation from Geng et al. (1983) was modified, and the volumetric friction of shale was set equal to ze:o with an assumption that there was not much contribution from clay minerals at this site to the dielectric-constant values. The modified equation is:

$$
\Sigma^{c}=1.67+\left(2.44 S_{w v}-0.39\right)+1.77 v_{s h}
$$

where

$$
\begin{aligned}
& \Sigma \text { is dielectric constant readings from log, } \\
& \mathrm{c} \text { is dielectric cementation factor, } \\
& \mathrm{S}_{\mathrm{wV}} \text { is moisture content of tuff, and } \\
& \mathrm{V}_{\mathrm{sh}} \text { is volumetric friction of shale in the tuff. }
\end{aligned}
$$

For volcanic tuff, the dielectric cementation factor, c, was unknownes Various c values were used for borehole USW UZ-1, and moisture-content values were determined. Comparison of the moisture-content profile from drill cuttings with the calculated moisture-content profile was very unrealistic when the calculations were made using a dielectric: 

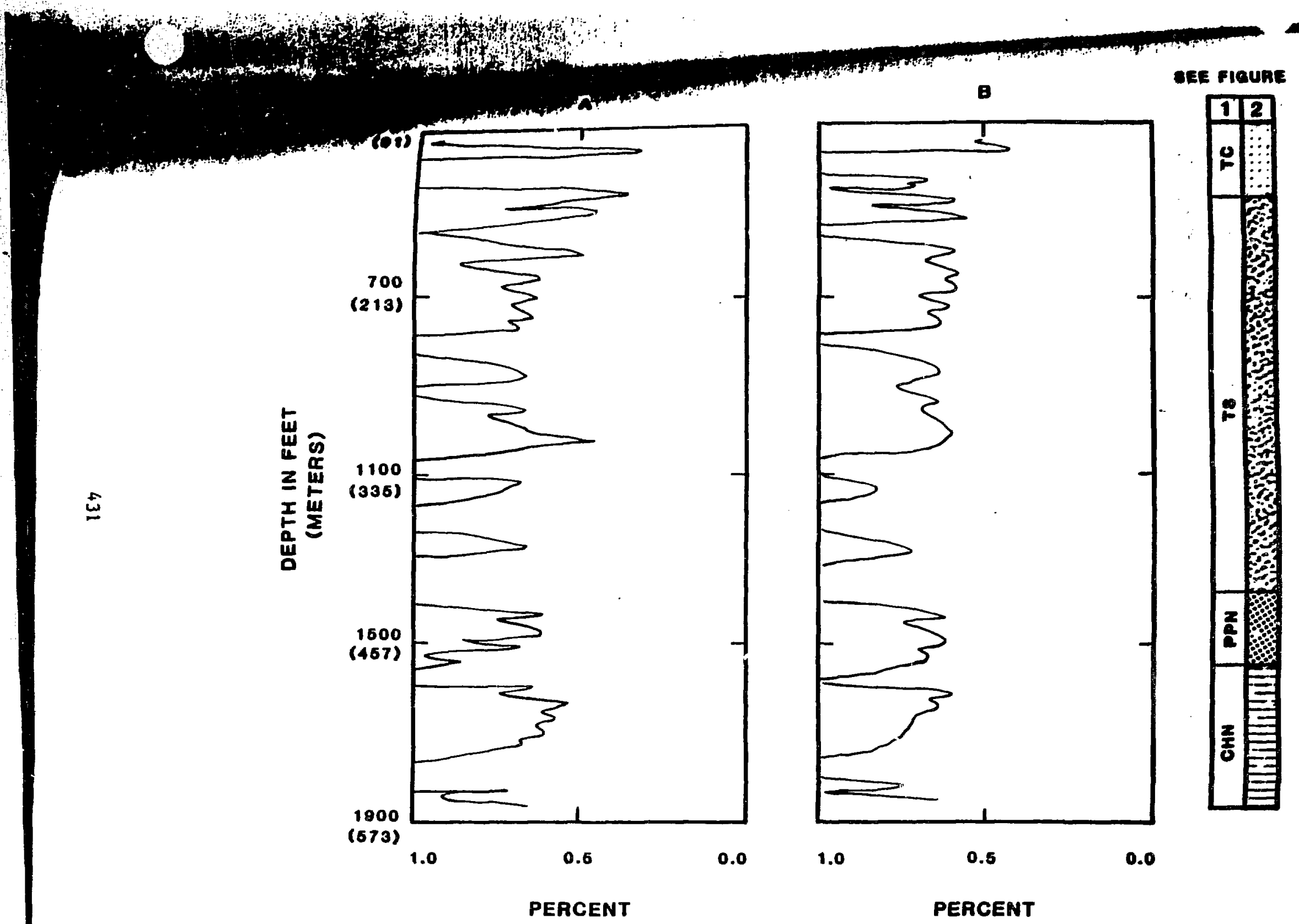

Figure 4. Borehole USW UZ-1, water saturation derived from--(A) formation resistivity and porosity, and (B) dielectric constant and porosity. 

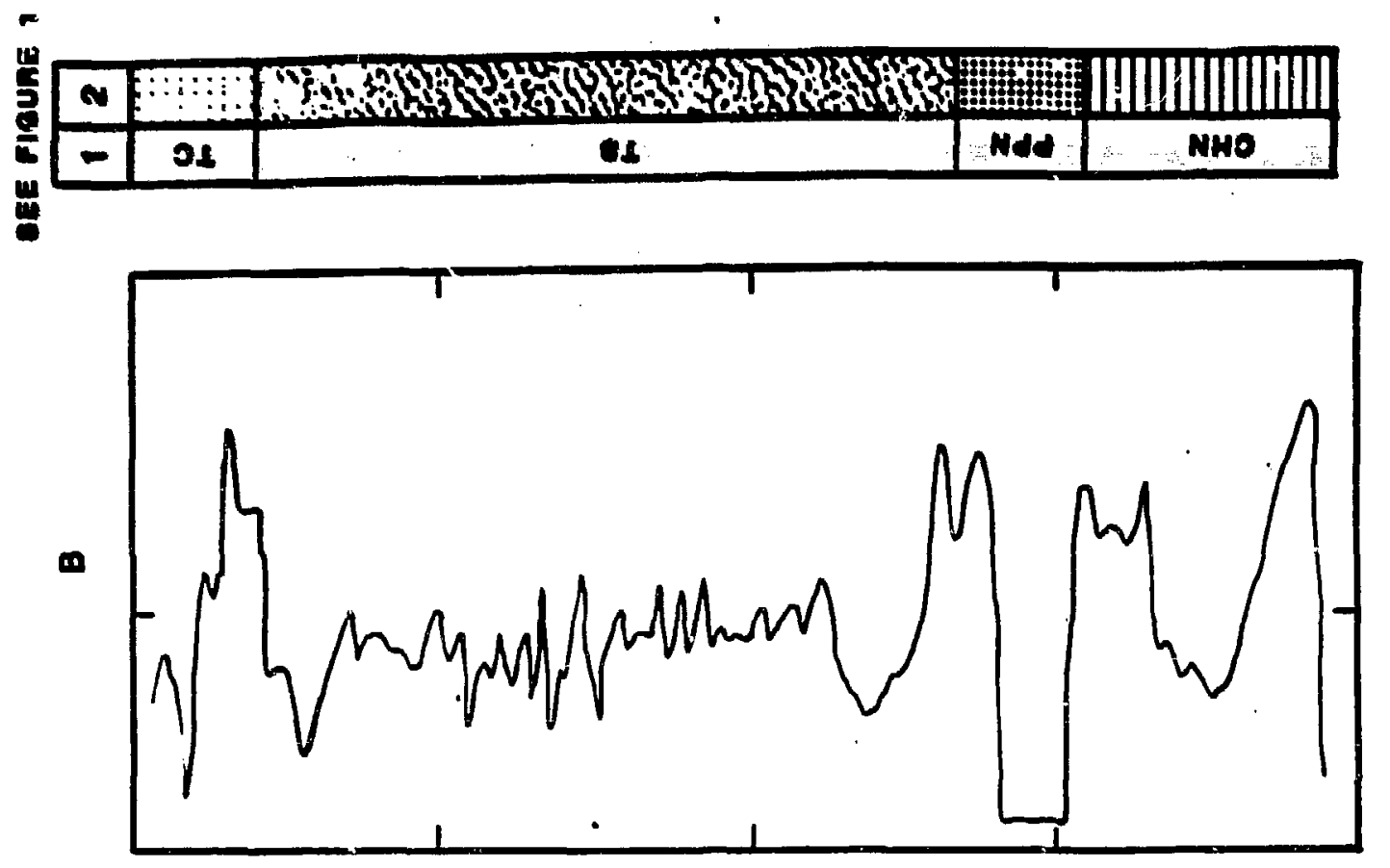

:

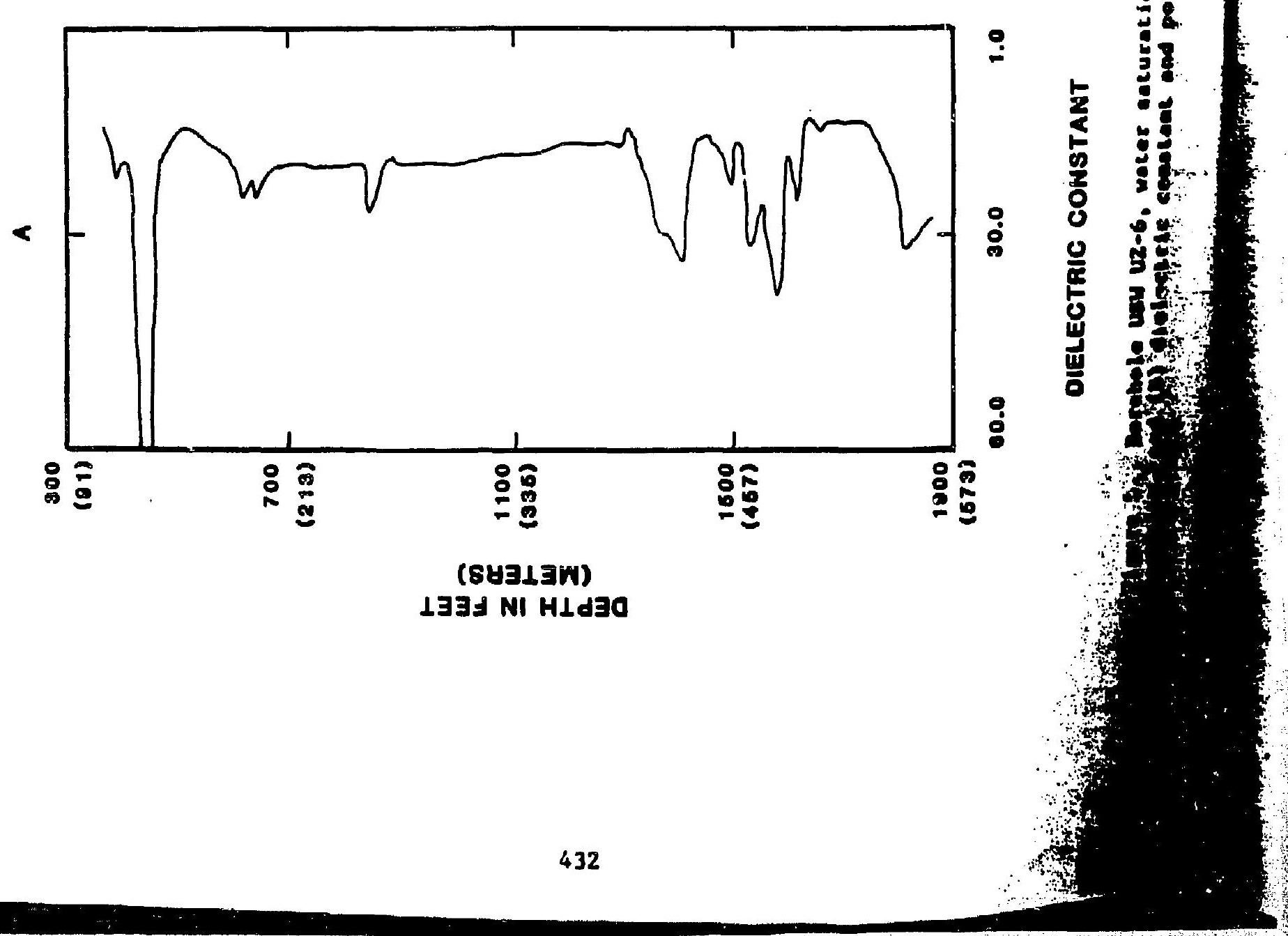


cenitition factor of 0.3 . Later, other values for the dieleetric cementation factor were tested. It was deternined that the best comparison betwen the wisture-content profile froe drill cuttings and the calculated wisture-conteat values was obtained when the calculations were ade uning dielectric cementation factor of 0.1 to 0.13 for veriour goologte nubers. This moisture profile was compared with the one obtatned froc drill cuttinga; for borehole USW UZ-1 and for most of borehole USil UZ-6, correlation was good. The correlation of (A) dielectric-log-derived moisture profile, (B) drill-cuttings-derived moisture profile, and (C) the induction $\log$, is shown in Figure 6 for borehole USW UZ-1, and in Figure 7 for borehole USW UZ-6. Moisturecontent.values were consistently greater on profiles derived frov dielectric loga than on profiles derived from drill cuttings. For the interval from 1,350 feet to 1,400 feet ( 411 to 426 meters) in borehole USW UZ-6, the moisture curve derived from the dielectric iog indicated substantial moisture content, but the profile derived from drill cuttings indicated little moisture content. The drilling log indicated that drilling was suspended at this interval for 2 days, which delayed the sampling of the drill cuttings by about 3 days: Later, the induction $l_{8}$ was studied again to recheck the moisture profile derived from the dielectric $\log$; the induction $\log$ indicated less resistivity corresponding to substantial moisture content. For the same interval, the epithermal-neutron $\log$ also correlated very well with the moisture profile derived from the dielectric 108 . This 108 indicated greater hydrogen concentration (fewer API neutron counts) for this interval, which was interpreted as having a substantial moisture content. The epithermal-neutron $\log$ also was used for comparing the other zones with substantial moisture content in both the boreholes with the profiles derived from drill cuttings and the dielectric logs; the correlation was excellent. The correlation of (A) dielectrj.c 108 and (B) epithermal-neutron $\log$ for the moisture zones is shown in Figure 8 for borehole USW UZ-1, and in Figure 9 for borehole USW UZ-6.

\section{Conclusions}

This study determined that geophysical well logs obtained reliable information even under less than optimum borehole conditions. Drill cuttings also supplied very useful information; however, other sources of information were necessary for measuring characteristics such as moisture content, which is sensitive to exposure to air and to timing of the sampling. The thickness of the moisture zones vary within a few feet from one $\log$ to another. Results need to be evaluated qualitatively rather than quantitatively. For future operations in boreholes of such large size, logging companies could be asked to change the source-detector spacing of nuclear-logging tools or the transmitter-receiver spacing of electromagnetic tools to provide better quality logs. 


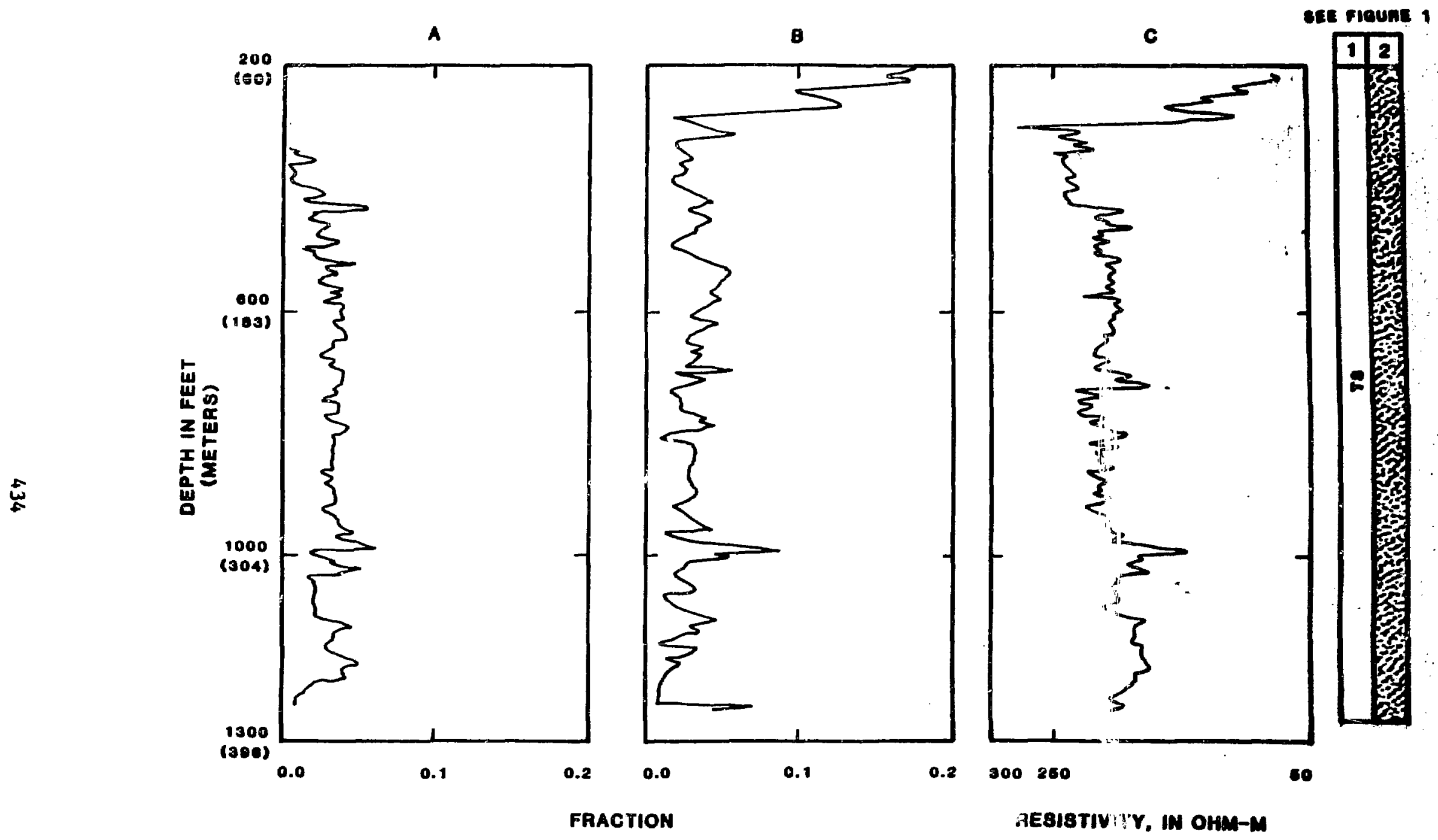

Eigure 6. Borehole USW UZ-1, moisture-content profiles derived from--(A) dielectric log, (B) drill cuttings, and (C) induction log. 


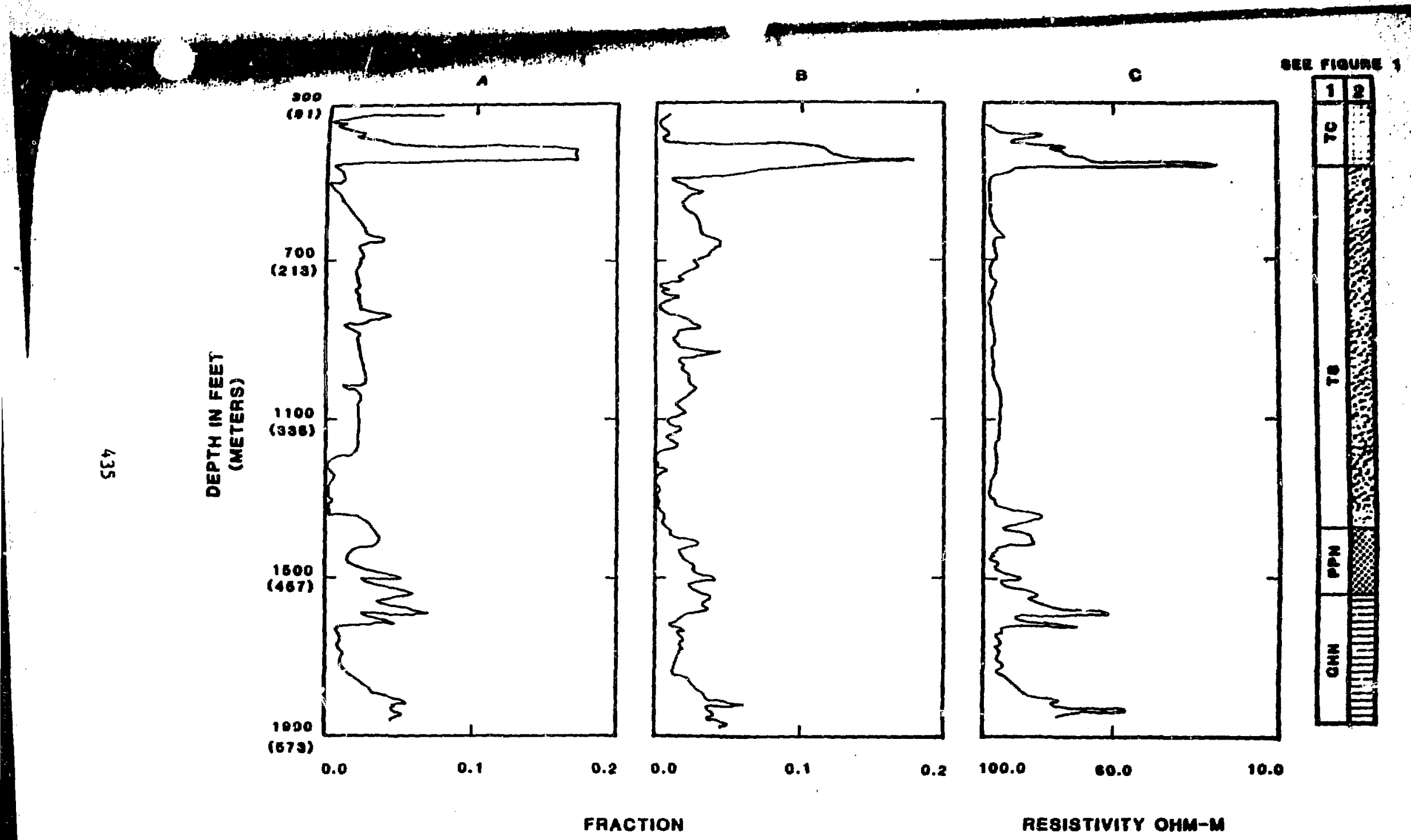
Figure 7 . Borehole USW UZ-6, moisture-content profiles derived from-- (A) dielectric log,
(B) drili cuttings, and (C) induction log. 


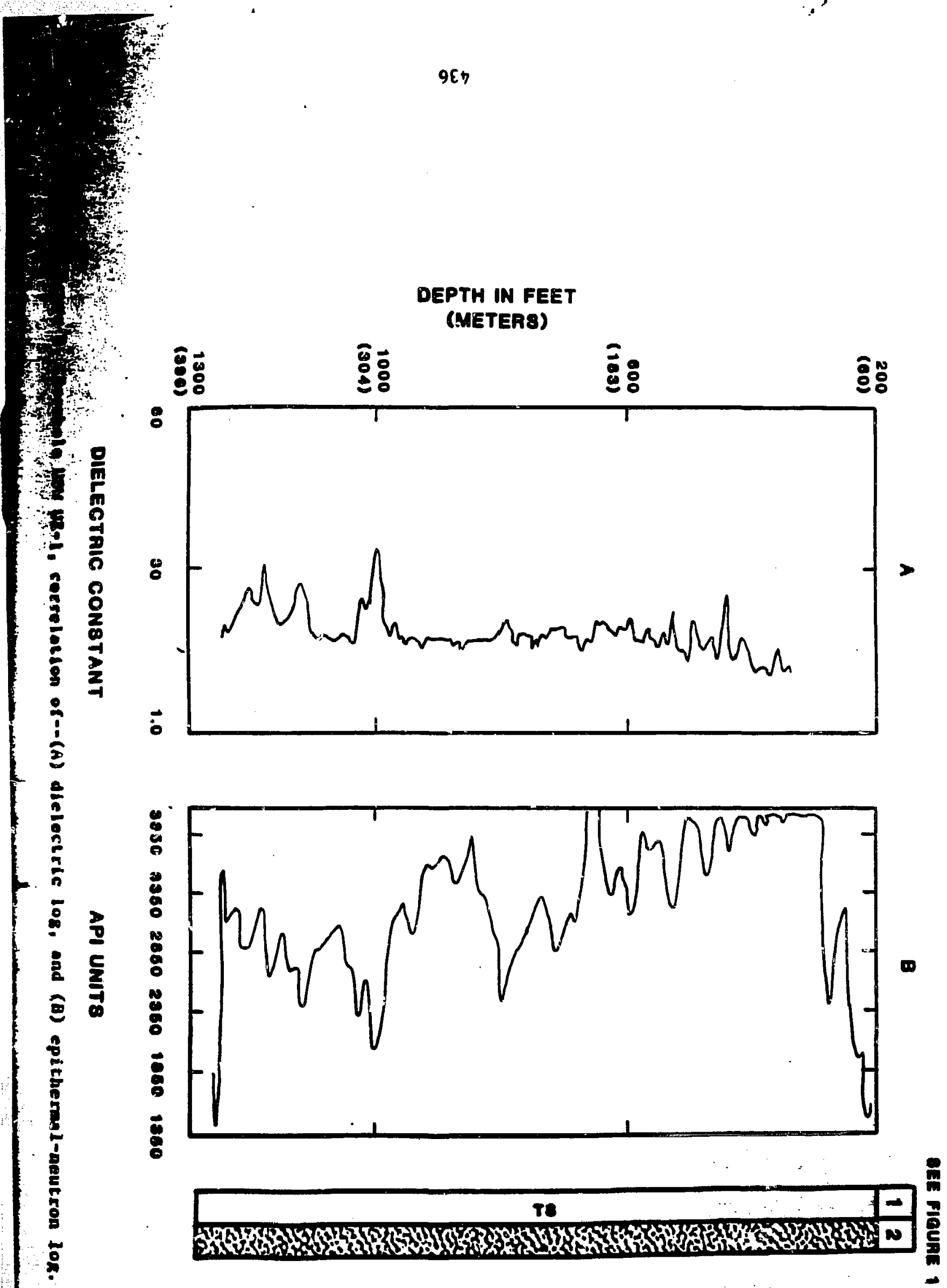




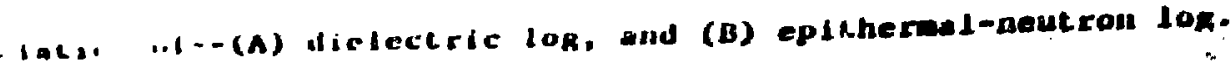
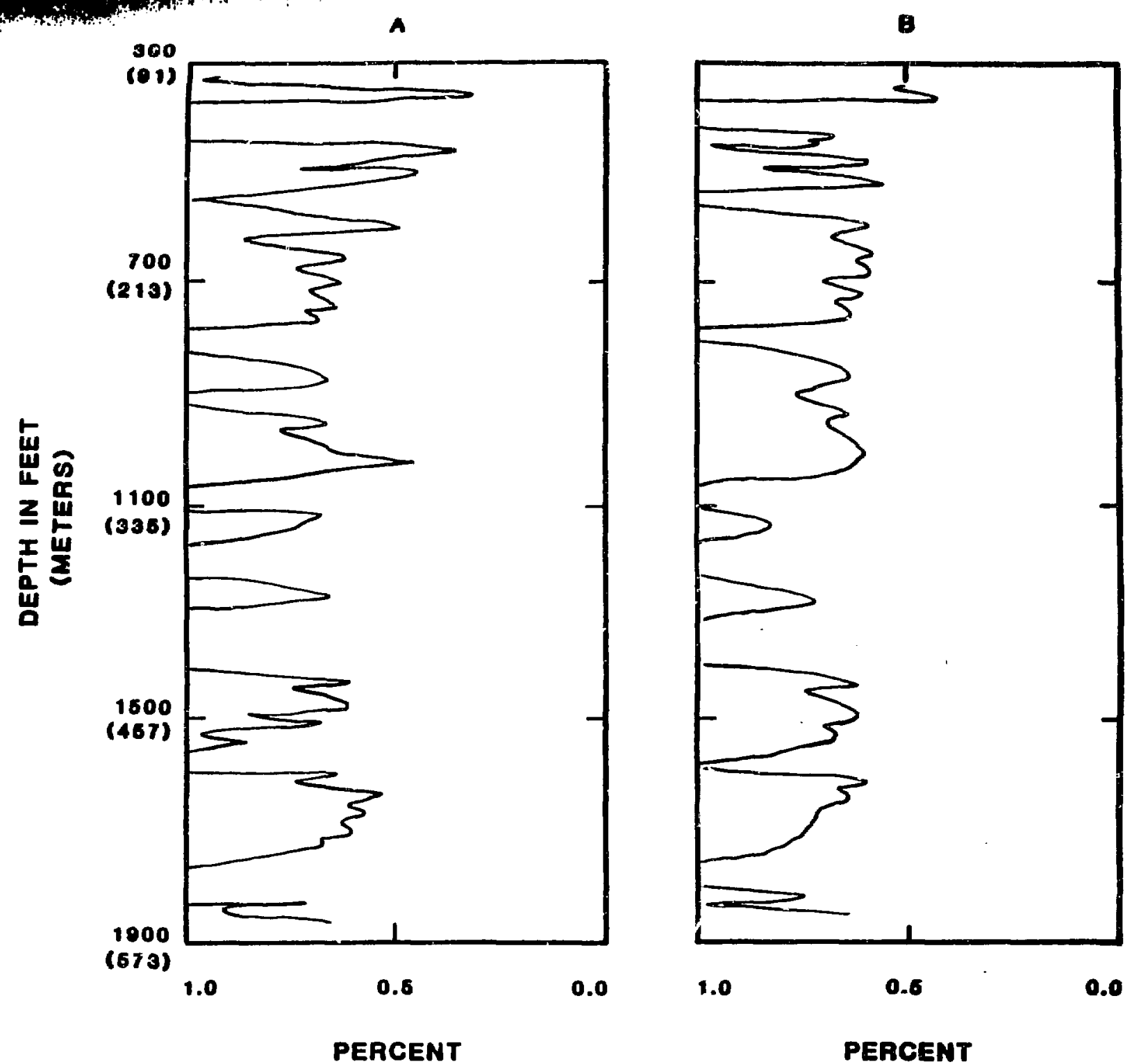

SER Fioune 1 12

Figure 9. UZ-6, correlation of-(A) dielectric 108 , and (B) epithereal-neutron log. 
References

Cos, P.T. and W.F. Waren, 1983. Developent and testing of Texaco 011 Compar' dielectric loggins. Society of Professional Well Los Anlyat Symosiu Transactions. v. 1 , paper no. H.

Gens; X., Y. Tinzu, L. Da and Z. Shutang. October I983. Dielectric log. A logzing athod for determiniag oil saturation. Journal of Petroleu TechnologV, PF. 1797-1805.

Pirson, S.J. 1983. Handtook of Well Log Analysis. McGraw Hill Publishing Co., $326 \mathrm{pg}$.

Shen, P.N. 1980. The dielectric and conductivity response of sedimentary rocks. Society of Petroleun Engineers, Technical Paper No. 9379.

Sherma, M.N. 1983. The determination of cementation exponent using high frequency dielectric measurement. Society of Profersional Well Lo8 Analyst Symposium Transactions, v. 2, paper no. DD.

Whitfield, M.S. 985 . Vacuum drilling of unsaturated tuff at a potential radioactive waste repository, Yucca Mountain, Nevada: in Proceedings, National Water Well Association Conference on Characterization and Monitoring of the Vadose (Unsaturated) Zone, Denver, Colorado, Novemter 19-21, 1985.

Biographical Sketch

Ibrahim Palaz received his bachelor of science degree in geophysics and geology from the University of Is*anbul, Turkey, in 1978. He received his master of science degree in geophysics from Colorado School of Mines, Golden, in 1985 . He is currently enrolled in the doctoral progran at Colorado School of Mines and is a contract employee of the U.S. Geological Survey. His address is: U.S. Geological Survey, Box 25046, MS 416, Denver Federal Center, Denver, CO 80225.

\section{DISCLAIMER}

This report was prepared as an account of work sponsored by an agency of the United States Government. Neither the United States Government nor any agency thereof, nor any of their employees, makes any warranty, express or implied, or assumes any legal liability or respons:bility fer the accuracy, completeness, or usefulness of any information, apparatus, product, or process disclosed, or represents that its use would not infringe privately owned rights. Reference herein to any specific commercial product, process, or service by trade name, trademark, manufacturer, or otherwise does not necessarily constitute or imply its endorsement, recommendation, or favoring by the United States Government or any agency thereof. The views and opinions of authors expressed herein do not necessarily state or reflect those of the United S'́ates Government or any agency thereof. 